\section{> Gjesteskribent}

\author{
Espen Schaanning
}

Professor i idéhistorie, Universitetet i Oslo

\title{
Rettspsykiatrisk spådomskunst
}

\section{Kan vi stole på rettpsykiaternes kliniske skjønn i forvaringssaker?}

Jeg tar av og til turen til Ila fengsel for å besøke «Conrad». Han sitter på 11 års forvaring, med minstetid på sju år, og har nå sonet over åtte av dem. Til nå har han ikke hatt en eneste permisjon, kun noen få fremstillinger lutgang fra fengslet sammen med betjenter). Conrad har en lang kriminell historie bak seg, og alt sammen er knyttet til rus. I fengslet er han blitt ilagt disiplinærstraff utallige ganger for kjeftbruk, men han har aldri utøvd vold overfor betjenter eller medfanger. Nå får han Ritalin mot AD/HD og metadon for sin rusavhengighet.

Conrad begjærte seg nylig prøveløslatt fra forvaring, dvs. han gikk rettens vei for å få prøveløslatelse, siden lla ikke har villet gi slipp på ham. Det han ba om, var en prøveløslatelse der han hver dag skulle melde seg og ta urinprøve. Brudd på reglene eller tegn på rus ville automatisk føre ham sporenstreks tilbake til Ila. Alle vitner fortalte nemlig det samme: Edru var Conrad en beskjeden og grei kar, det var når han drakk og ruset seg på andre stoffer, at det kunne gå galt. Retten ga imidlertid medhold til påtalemaktens påstand om fortsatt forvaring. Det er påtalemakten som har bevisbyrden for om vilkårene for fortsatt forvaring er oppfylt, og deres viktigste «bevis» var rettspsykiaternes rapport (bare én av dem møtte i retten). Rettspsykiateren var utvilsomt den viktigste figuren gjennom hele rettsprosessen. Jeg var der, og så det selv. Det var dypt foruroligende.
Først av alt: plasseringen. I tingretten satt han sammen med aktoratet, med forsvarer og tiltalte på motsatt side; i lagmannsretten var han plassert sammen med dommerne, på gulvet foran dem, med ansiktet vendt samme vei. Disse plasseringene symboliserte klart hans funksjon: på en og samme tid en slags anklager og dommer.

Dernest språket. Vi fikk ikke bare høre at Conrad hadde fått diagnosene «F60.2 Dyssosial personlighetsforstyrrelse» og «F 19.2 Psykiske lidelser og atferdsforstyrrelser». Men psykiateren kunne også fortelle at Conrad var dårlig til å forholde seg til «grensesetting» og til å ta «irettesettelser». Dette er jo termer hentet fra barneoppdragelsen, og jeg grep meg i å tenke: Mon tro hvordan denne psykiateren ville ha reagert hvis man spurte ham om han selv var god til å ta grensesetting og irettesettelser. Han ville vel ha tatt det som en spøk eller blitt fornærmet. Slik ville i alle fall jeg ha reagert.

Og endelig viktigst: Rollen som spåmann. I sin forklaring hevdet rettspsykiateren at det ikke ville være forsvarlig å gi Conrad prøveløslatelse, og det var dette vitnesbyrdet retten la til grunn. I tingrettsdommen står det å lese at retten tok «utgangspunkt i opplysninger og vurderinger gitt av de sakkyndige» og viste til at «de sakkyndige ikke kan anbefale prøveløslatelse». Som bevis siterte de fra psykiaternes rapport og bruk av predikasjonsinstrumentet HCR-20: «HCR-20 indikerer at han p.t. ikke vil klare seg i et utemiljø. ved at det ikke foreligger progresjon i anstalt». Videre het det at «de sakkyndige har ved sin risikovurdering pekt på hans lave frustrasjonsterskel, hans aggressive utbrudd, trusler og utageringer».

Her bør man minne om det jeg gjerne kaller «bur-løve-dilemmaet»: Hvis du vil undersøke en løves atferd, kan du sette den i bur og observere hvordan den oppfører seg. Kanskje vandrer den hvileløst omkring og knurrer og bærer seg. Men om den også vil oppføre seg slik i det fri, er et åpent spørsmål. Atferden kan være en reaksjon på å bli satt i bur. Det er derfor umulig å slutte fra buratferd til atferd i det fri. Slik er det med forvaringsfanger også. Frustrasjoner og utageringer kan være reaksjoner på å sitte i fengsel, og de kan derfor ikke uten videre legges inn i en risikovurdering for voldelig atferd i det fri. Da forsvareren gikk psykiateren på klingen i dette spørsmålet, måtte han til slutt innrømme at atferd i anstalt i grunnen måtte ilegges minimal vekt.

Og da er man ved sakens kjerne: Det eneste relevante datagrunnlaget som var nytt i forhold til det som forelå da rettspsykiaterne vurderte Conrad for åtte år siden, var det «kliniske» intervjuet psykiaterne nå hadde foretatt av ham i løpet av to og en halv time. Ny diagnose og risikovurdering av Conrads åtte år med livserfaring i fengsel ble altså stilt på bakgrunn av et par timers samtale, og dernest brukt som det avgjørende «bevis» i retten. Spørsmålet er: Kan legelauget være bekjent av en slik praksis? Er det ikke bedre å si som Sokrates «Jeg vet at jeg ikke vet»?

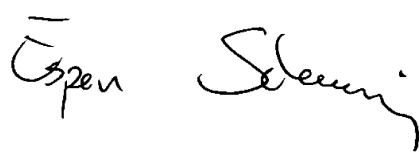

